\title{
Tetramethylfluoroformamidinium hexafluorophosphate (TFFH)/ benzyltriphenylphosphonium dihydrogen trifluoride (PTF): a unique reagent for the conversion of carboxylic acids to the corresponding alcohols as well as hydroxamic acids
}

\author{
Ayman El-Faham, ${ }^{a *}$ Sherine N. Khattab, ${ }^{a}$ and Mohamed Abdul-Ghani ${ }^{b}$ \\ a Department of Chemistry, Faculty of Science, Alexandria University, \\ Ibrahimia 21321, P.O. Box 426, Alexandria, EGYPT \\ ${ }^{b}$ Department of Chemistry, Faculty of Science, Beirut Arab University, \\ P.O. Box 11-5020, Beirut, LEBANON \\ E-mail:Aymanel_faham@,hotmail.com
}

\begin{abstract}
The present work describes the utility of TFFH (1) for the conversion of carboxylic acids to the corresponding alcohols $\mathbf{4}$ as well as the hydroxamic acids $\mathbf{5}$ in the presence or absence of the fluoride additive PTF (3). The addition of the fluoride additive $\mathbf{3}$ during the activation step improves the yield and purity of the products, due to the fast activation to the acid fluoride derivatives as observed from IR examination.
\end{abstract}

Keywords: Tetramethylfluoroformamidinium hexafluorophosphate (TFFH), benzyl triphenylphosphonium dihydrogen trifluoride (PTF), alcohols, hydroxamic acids

\section{Introduction}

Halouronium salts are frequently described as good reagents especially for coupling of sterically hindered $N$-substituted or $N, N$-disubstituted amino acids, which is not easily carried out under standard conditions. ${ }^{1} \quad$ Tetramethylfluoroformamidinium hexafluorophosphate 1 (TFFH), was introduced by Carpino and El-Faham ${ }^{2}$ as a benign substitute for the corrosive cyanuric fluoride 2. Cyanuric fluoride $\mathbf{2}$ was reported as a mild reagent, suitable for the preparation of acyl fluorides even when unsaturated double bonds, hydroxyl groups, or aromatic rings are present. ${ }^{3,4} \mathrm{TFFH}$ has been shown to act as a coupling reagent that proceeds via in situ conversion to an acid fluoride. ${ }^{2,5}$ Acyl fluorides, having a greater stability than the corresponding chlorides towards neutral oxygen nucleophiles such as water and methanol, appear to be of equal reactivity toward anionic nucleophiles and amines. ${ }^{6}$ Recently, Fmoc-, ${ }^{7}$ Boc-, or Z-amino acid fluorides ${ }^{8}$ have been found to be stable and fast acylating reagents for peptide bond formation. Moreover, TFFH 
(1) was reported as a convenient reagent for the preparation of isothiocyanates from the corresponding primary amines in the presence of carbon disulfide. ${ }^{9}$ In a recent paper, ${ }^{10}$ we described TFFH as a useful reagent for the conversion of carboxylic acids into anilides, hydrazides as well as acyl azides. The present work extends the utility of TFFH (1) for eventual conversion of carboxylic acids to the corresponding alcohols and hydroxamic acids. Moreover, addition of the fluoride additive (PTF, 3) ${ }^{11}$ during the activation step with $\mathbf{1}$, improves the yield and purity of the desired products.

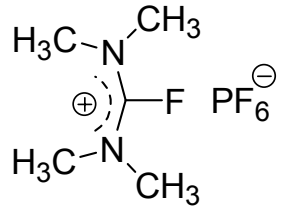

TFFH, 1<smiles>Fc1nc(F)nc(F)n1</smiles>

2

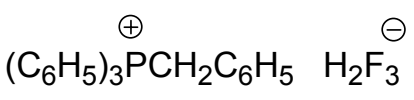

PTF, 3

\section{Results and Discussion}

Carboxylic acids $\mathbf{4 a - h}$ were converted into the corresponding fluorides by treatment with $\mathbf{1}$ in the presence of triethylamine or diisopropylethylamine as a base (Scheme 1). Acyl fluorides were then reduced in situ to the primary alcohols by sodium borohydride with dropwise addition of methanol at room temperature. A variety of acids, such as benzoic acid (4a), 2-nitrobenzoic acid (4b) phenylacetic acid (4c), and 9-fluorene carboxylic acid (4d), Boc-Phe-OH (4e), Z-Phe-OH (4f), Fmoc-Leu-OH (4g), Fmoc- Glu(OBn)-OH (4h), were converted into the corresponding alcohols 5a-h respectively in very good yields (Table 1). Addition of PFT (3) during the activation of the carboxylic acid with TFFH improves the yield of the products (Table 1).

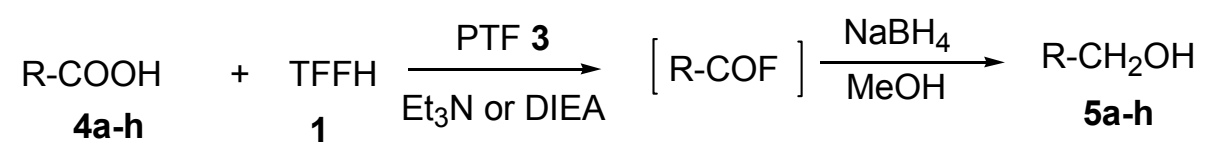

\section{Scheme 1}

It can be observed from Table 1 that TFFH alone gave lower yields than the TFFH/PTF procedure in case of aryl carboxylic acids (4a-d). The deficiency was traced to inefficient conversion to the acid fluorides, which under the conditions used was accompanied by the formation of the corresponding symmetric anhydrides as observed from infrared examination during the activation step. ${ }^{10}$ On the other hand it is shown that if a fluoride additive PTF (3) is present during the activation step, the corresponding symmetric anhydrides are avoided and a maximum yield of acid fluoride is obtained. ${ }^{11}$ 
Table 1. Reduction of carboxylic acids and $N$-protected amino acids to alcohols

\begin{tabular}{|c|c|c|c|c|}
\hline $\mathrm{RCOOH}$ & $\mathrm{RCH}_{2} \mathrm{OH}^{\mathrm{a}}$ & $\begin{array}{l}\text { Yield }(\%)^{\mathrm{b}} \\
\text { TFFH } \\
(\mathrm{TFFH} / \mathrm{PT} \\
\mathrm{F}) \\
\end{array}$ & $\begin{array}{l}\mathrm{mp} .{ }^{\circ} \mathrm{C} \\
\left(\text { lit. },{ }^{\circ} \mathrm{C}\right)\end{array}$ & {$[\alpha]_{D}^{25}$} \\
\hline $\mathbf{4 a ~} \mathrm{C}_{6} \mathrm{H}_{5}-\mathrm{COOH}$ & 5a $\mathrm{C}_{6} \mathrm{H}_{5} \mathrm{CH}_{2} \mathrm{OH}$ & $78(93)$ & - & - \\
\hline 4b $2-\mathrm{NO}_{2}-\mathrm{C}_{6} \mathrm{H}_{4}-\mathrm{COOH}$ & 5b $2-\mathrm{NO}_{2}-\mathrm{C}_{6} \mathrm{H}_{4} \mathrm{CH}_{2} \mathrm{OH}$ & $80(94)$ & - & - \\
\hline $4 \mathbf{c ~} \mathrm{C}_{6} \mathrm{H}_{5}-\mathrm{CH}_{2}-\mathrm{COOH}$ & 5c $\mathrm{C}_{6} \mathrm{H}_{5} \mathrm{CH}_{2}-\mathrm{CH}_{2} \mathrm{OH}$ & $79(91)$ & - & - \\
\hline $\begin{array}{l}\text { 4d 9-Fluorene carboxylic } \\
\text { acid }\end{array}$ & 5d 9-Fluorenylmethanol & $75(92)$ & $\begin{array}{c}97 \\
(100)^{3 a}\end{array}$ & - \\
\hline 4e Boc-Phe-COOH & 5e Boc-Phe- $\mathrm{CH}_{2} \mathrm{OH}$ & $84(89)$ & $\begin{array}{c}94-95 \\
(94.5)^{3 b}\end{array}$ & $\begin{array}{c}-23.5 \\
\left(\mathrm{c} 1, \mathrm{CHCl}_{3}\right)\end{array}$ \\
\hline 4f Z-Phe-COOH & $5 f \mathrm{Z}-\mathrm{Phe}-\mathrm{CH}_{2} \mathrm{OH}$ & $80(84)$ & $\begin{array}{c}91-92 \\
(90-91)^{3 b}\end{array}$ & $\begin{array}{c}-41.1 \\
(\mathrm{c} 1, \mathrm{MeOH})\end{array}$ \\
\hline 4g Fmoc-Leu-COOH & 5 g Fmoc-Leu- $\mathrm{CH}_{2} \mathrm{OH}$ & $88(91)$ & $\begin{array}{l}130-131 \\
(130)^{3 b}\end{array}$ & $\begin{array}{c}-17.4 \\
\left(\mathrm{c} 1, \mathrm{CHCl}_{3}\right)\end{array}$ \\
\hline 4h Fmoc-Glu(OBn)-COOH & 5h Fmoc-Glu(OBn $) \mathrm{CH}_{2} \mathrm{OH}$ & $81(85)$ & $\begin{array}{c}91 \\
(91-92)^{3 b}\end{array}$ & $\begin{array}{c}-9.0 \\
\left(\mathrm{c} 1, \mathrm{CHCl}_{3}\right)\end{array}$ \\
\hline
\end{tabular}

${ }^{a}$ The products 5a-h were identified by their physical constants, IR, ${ }^{1} \mathrm{H}$ NMR data and comparison with data reported in the literature.

${ }^{b}$ Yields are of isolated and purified products

${ }^{c}$ The present method (TFFH alone or TFFH/PTF) proceeds with retention of optical purity as indicated by comparison of the specific rotation values with those reported in the literature. ${ }^{3}$

$N$ - Protected amino alcohols are important synthetic intermediates, particularly in the synthesis of peptides that are potent inhibitors of proteases, ${ }^{12}$ and are also incorporated at the Cterminal of biological active peptides. ${ }^{13}$ The conversion of amino acids into alcohols by chemoselective reduction of their corresponding mixed anhydrides ${ }^{14}$ and $N$-carboxyanhydrides ${ }^{15}$ with sodium borohydride has also been reported. In the present work, a variety of $N$-protected amino acids $4 \mathbf{e}-\mathbf{h}$ were converted rapidly into alcohols $\mathbf{5} \mathbf{e}-\mathbf{h}$ by in situ reduction of their corresponding acid fluorides with sodium borohydride in high yield. There was not much difference between TFFH alone or the TFFH/PTF method (Table 1), because the symmetric anhydride was not observed during IR examination.

The present work also describes a useful method for the preparation of a variety of hydroxamic acids using TFFH (1) alone, or in the presence of the fluoride additive PTF (3). Carboxylic acids 6a-b as well as $N$-protected amino acids $\mathbf{6 c - i}$ were activated for 5 min with TFFH alone, or the TFFH/PTF mixture, in the presence of triethylamine $\left(\mathrm{Et}_{3} \mathrm{~N}\right)$ or diisopropylethyl amine (DIEA) as a base in dichloromethane (DCM) followed by addition of 
hydroxylamine. $\mathrm{HCl}$ at $0{ }^{\circ} \mathrm{C}$. The reaction mixture was warmed to room temperature and then stirred at room temperature overnight. After workup, the products were obtained in high yields and purity (Table 2, Scheme 2). There was no difference in the yield and purity for urethane $N$ protected amino acids with the use of TFFH alone or TFFH/PTF. However, there was a difference in the yield in case of aryl carboxylic acids; TFFH/PTF gave better yields and purity than TFFH alone (Table 2).

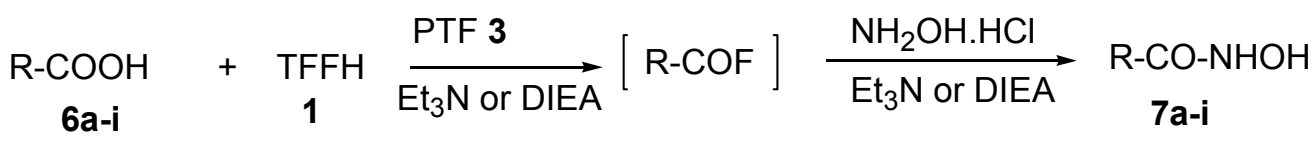

\section{Scheme 2}

Table 2. Preparation of aryl hydroxamic acids and $N$-protected amino hydroxamic acids using TFFH or TFFH/PTF*

\begin{tabular}{|c|c|c|c|c|}
\hline $\mathrm{R}-\mathrm{COOH}$ & $\mathrm{R}-\mathrm{NHOH}^{\mathrm{a}}$ & $\begin{array}{l}\text { Yield }(\%)^{\mathrm{b}} \\
\text { TFFH } \\
(\mathrm{TFFH} / \mathrm{PTF})\end{array}$ & $\begin{array}{l}\mathrm{mp} \cdot\left({ }^{\circ} \mathrm{C}\right) \\
\left(\text { lit. },{ }^{\mathrm{o}} \mathrm{C}\right)\end{array}$ & {$[\alpha]^{25{ }^{c}}$} \\
\hline $\mathbf{6 a ~} \mathrm{C}_{6} \mathrm{H}_{5}-\mathrm{COOH}$ & 7a $\mathrm{C}_{6} \mathrm{H}_{5} \mathrm{CONHOH}$ & $81(95)$ & $\begin{array}{c}123 \\
(123-124)^{17}\end{array}$ & \\
\hline 6b $\mathrm{C}_{6} \mathrm{H}_{5}-\mathrm{CH}_{2}-\mathrm{COOH}$ & $7 \mathbf{b} \mathrm{C}_{6} \mathrm{H}_{5}-\mathrm{CH}_{2}-\mathrm{NHOH}$ & $80(91)$ & Oil (oil) ${ }^{17}$ & \\
\hline 6c Boc-Leu-OH & 7c Boc-Leu-NHOH & $90(94)$ & Oil (oil) ${ }^{17}$ & $\begin{array}{c}-8.9 \\
(\mathrm{c} 1, \mathrm{MeOH})\end{array}$ \\
\hline 6d Boc-Phe-OH & 7d Boc-Phe-NHOH & $89(93)$ & Oil (oil) ${ }^{17}$ & $\begin{array}{c}+25.7 \\
(\mathrm{c} 1, \mathrm{EtOH})\end{array}$ \\
\hline 6e Boc-Glu(OBn)-OH & 7eBoc-Glu(OBn)-NHOH & $88(91)$ & $\begin{array}{c}83 \\
(82-83)^{17}\end{array}$ & $\begin{array}{c}+27.8 \\
\text { (c } 1, \mathrm{MeOH})\end{array}$ \\
\hline 6f Z-Phe-OH & 7f Z-Phe-NHOH & $80(84)$ & $\begin{array}{c}91-93 \\
(90-91)^{17}\end{array}$ & $\begin{array}{c}-38.6 \\
(\mathrm{c} 0.5, \mathrm{MeOH})\end{array}$ \\
\hline 6g Z-Val-OH & 7g Z-Val-NHOH & $90(92)$ & Oil (oil) ${ }^{17}$ & $\begin{array}{c}+10.5 \\
(\mathrm{c} 1, \mathrm{MeOH})\end{array}$ \\
\hline 6h Fmoc-Phe-OH & 7h Fmoc-Phe-NHOH & $88(91)$ & $\begin{array}{c}150-151 \\
(150-152)^{17}\end{array}$ & $\begin{array}{c}-39.3 \\
\text { (c 1, DMF) }\end{array}$ \\
\hline 6i Fmoc-Leu-OH & 7i Fmoc-Leu-NHOH & $94(96)$ & $\begin{array}{c}115 \\
(114-116)^{17}\end{array}$ & $\begin{array}{c}-25.4 \\
\text { (c 1, DMF) }\end{array}$ \\
\hline
\end{tabular}

*All compounds 7a-i gave a positive test for hydroxamic acids on treatment with iron (III) chloride solution. ${ }^{16}$

${ }^{a}$ IR and ${ }^{1} \mathrm{H}$ NMR spectra of compounds 7a-i were in accordance with their structure

${ }^{b}$ Yields are of isolated and purified products 
${ }^{c}$ The present method proceeds with retention of optical purity as indicated by comparison of the specific rotation values with those reported in the literature. ${ }^{17}$

\section{Conclusions}

The TFFH/PTF procedure provides a general, rapid, and convenient method for the conversion of carboxylic acids in the presence of $\mathrm{NaBH}_{4}$ into alcohols as well as to hydroxamic acids. The present method proceeds also with retention of optical purity as indicated by comparison of the specific rotation values with those reported in the literature.

\section{Experimental Section}

General Procedures. Melting points was obtained in open capillary tubes using a melting heating apparatus and are uncorrected. NMR spectra were recorded using a Bruker $300 \mathrm{MHz}$ or a Jeol $500 \mathrm{MHz}$ instrument with TMS as internal standard. Infrared spectra were obtained using a Shimadzu 8300 series Fourier Transform instrument. Optical rotations were measured at $25{ }^{\circ} \mathrm{C}$. All asymmetric amino acids derivatives were of the L-configuration and were purchased from Fluka Chemical Co. All solvents and chemical were of reagent grade and used without further purification. Silica gel 60 (70-230 mesh, Merck) was used for column chromatography.

General Procedure for the Preparation of Alcohols (5a-h): TFFH or TFFH/PTF (2 mmol, $0.528 \mathrm{~g} / 0.824 \mathrm{~g}$ respectively) was added to a stirred solution of the acid $4 \mathbf{a}-\mathbf{d}(2 \mathrm{mmol})$ and $\mathrm{Et}_{3} \mathrm{~N}$ (4 mmol, $0.404 \mathrm{~g}$ ) or $\mathrm{N}$-protected amino acid $4 \mathbf{e}-\mathbf{h}(2 \mathrm{mmol})$ and diisopropylamine (DIEA, 4 mmol, $0.516 \mathrm{~g})$ in $\mathrm{CH}_{2} \mathrm{Cl}_{2}(5 \mathrm{~mL})$, and kept under a $\mathrm{N}_{2}$ atmosphere at $0{ }^{\circ} \mathrm{C}$. After the mixture was stirred at $0{ }^{\circ} \mathrm{C}$ for about $1 \mathrm{~h}$, ice-cold water $(10 \mathrm{~mL})$ was added along with $\mathrm{CH}_{2} \mathrm{Cl}_{2}(20 \mathrm{~mL})$. The organic layer was separated, and the aqueous layer was extracted once with $\mathrm{CH}_{2} \mathrm{Cl}_{2}(10$ $\mathrm{mL})$. The combined organic layer was washed with ice-cold water $(10 \mathrm{~mL})$, dried $\left(\mathrm{MgSO}_{4}\right)$, and concentrated under reduced pressure to a small volume $(2 \mathrm{~mL}) . \mathrm{NaBH}_{4}(76 \mathrm{mg}, 2 \mathrm{mmol})$ was added in one portion, and $\mathrm{MeOH}(2 \mathrm{~mL})$ was then added dropwise over a period of $15-20 \mathrm{~min}$ at rt. The reaction mixture was neutralized with $1 \mathrm{~N} \mathrm{H}_{2} \mathrm{SO}_{4}$, and the organic solvents were evaporated under pressure. The residue was treated with EtOAc $(10 \mathrm{~mL})$ and $\mathrm{H}_{2} \mathrm{O}(5 \mathrm{~mL})$; the organic layer was separated, and the aqueous layer was extracted with EtOAc $(2 \times 10 \mathrm{~mL})$. The combined organic layers were washed consecutively with $1 \mathrm{~N}_{2} \mathrm{SO}_{4}(5 \mathrm{~mL})$ and $\mathrm{H}_{2} \mathrm{O}(2 \times 10$ $\mathrm{mL})$ and dried $\left(\mathrm{MgSO}_{4}\right)$, the solvent was evaporated under reduced pressure. The residue was purified by distillation or column chromatography using EtOAc/hexane (1:1) as an eluent.

General Procedure for the Preparation of Hydroxamic Acids (7a-i): TFFH or TFFH/PTF (2 mmol, $0.528 \mathrm{~g} / 0.824 \mathrm{~g}$ respectively) was added to a stirred solution of the acid $\mathbf{6 a - b}(2 \mathrm{mmol})$ and $\mathrm{Et}_{3} \mathrm{~N}$ (4 mmol, $0.404 \mathrm{~g}$ ) or $N$-protected amino acid $6 \mathbf{c - i}$ (2 mmol) and diisopropylamine (DIEA, $4 \mathrm{mmol}, 0.516 \mathrm{~g}$ ) in $\mathrm{CH}_{2} \mathrm{Cl}_{2}(10 \mathrm{~mL})$ and was activated for $5-10 \mathrm{~min}$ at $0{ }^{\circ} \mathrm{C}$. Hydroxylamine hydrochloride $(140 \mathrm{mg}, 2 \mathrm{mmol})$ and $\mathrm{Et}_{3} \mathrm{~N}$ or diisopropylamine $(2 \mathrm{mmol})$ were added to the reaction mixture at $0{ }^{\circ} \mathrm{C}$. After the addition, the reaction mixture was warmed to 
room temperature, and then stirred overnight, filtered through Celite, and the organic phase washed with $1 \mathrm{~N} \mathrm{HCl}(3 \times 5 \mathrm{~mL})$, a saturated $\mathrm{NaCl}$ solution $(2 \times 5 \mathrm{~mL})$, and dried $\left(\mathrm{MgSO}_{4}\right)$. The solvent was evaporated under reduced pressure to yield compounds 7a-i that were isolated without further purification.

\section{Acknowledgements}

Professor L. A. Carpino, Professor of Organic Chemistry, University of Massachusetts, Amherst, U. S. A. is thanked for his support and advice.

\section{References and Notes}

${ }^{\dagger}$ Abreviations used: TFFH $=$ Tetramethylfluoroformamidinium hexafluorophosphate; DCM = dichloromethane, EtOAc = ethylacetate; PTF = benzyl triphenylphosphonium dihydrogen trifluoride; DIEA = diisopropylethylamine; $\mathrm{Et}_{3} \mathrm{~N}=$ triethylamine; Z-Phe- $=N$-benzyloxycarbonyl phenylalanine; Z-Val- = N-benzyloxycarbonyl valine; Boc-Phe- $=N$-tert-butyloxycarbonyl phenylalanine; Boc-Leu- = N-tert-butyloxycarbonyl leucine; Fmoc-Leu- = 9fluorenylmethyloxycarbonyl leucine. Amino acids are abbreviated and designated following the rules of the IUPAC-IUB Commission of Biochemical Nomenclature (J. Biol. Chem., 1972, 247, 977.

1. (a) Tung, R. H; Rich, D. H. J. Am. Chem. Soc. 1985, 107, 4342. (b) Coste, J.; Dufour, M.N.; Pantaloni, A.; Castro, B. Tetrahedron Lett. 1990, 669. (c) Frérot, E; Coste, J.; Pantaloni, A.; Dufour, M.-N. ; Jouin, P. Tetrahedron 1991, 47, 259. (d) Coste, J.; Frérot, E.; Jouin, P. Tetrahedron Lett. 1991, 32, 1967. (e) Wenschuh, H.; Beyermann, M.; Krause, E.; Carpino, L. A.; Bienert, M. Tetrahedron Lett. 1993, 3733.

2. (a) Carpino, L. A.; El-Faham, A. J. Am. Chem. Soc. 1995, 117, 5401. (b) El-Faham, A. Org. Prep. Proced. Int. 1998, 30, 477. (c) El-Faham, A. Chemistry Lett. 1998, 671.

3. Olah,G.A.; Nojima, M.; Kerekes, I. Synthesis 1973, 487.

4. (a) Carpino, L. A. J. Org. Chem. 1980, 45, 4250. (b) Bertho, J.; Loffet, A.; Pinel, C.; Reuther, F.; Sennyey, G. Tetrahedron Lett. 1991, 32, 1303. (c) Kokotos, G.; Noula, C. J. Org. Chem, 1996, 61, 6994.

5. (a) Wenschuh, H. ; Beyermann, M.; Krause, E.; Brudel, M.; Winter, R.; Schümann, M.; Carpino, L. A.; Bienert, M. J. Org. Chem. 1994, 59, 3275. (b) Carpino, L. A.; Beyermann, M.; Wenschuh, H.; Bienert, M. Acc. Chem. Res. 1996, 29, 268.

6. (a) Bender, M. L.; Jones, M. L. J. Org. Chem. 1962, 27, 3771. (b) Swai, C. G.; Scott, C. B. J. Am. Chem. Soc. 1953, 75, 246. 
7. Carpino, L. A.; Sadat-Aalaee, D.; Chao, H. G.; DeSelms, R. H. J. Am. Chem. Soc. 1990, 112,9651 .

8. (a) Carpino, L. A.; Mansour, E. S. E.; Sadat-Aalaee, D. J. Org. Chem. 1991, 56, 2614. (b) Carpino, L. A.; Masnour, E. S. E.; El-Faham, A. J. Org. Chem. 1993, 58, 4162.

9. Boss, U.; Pedersen, B.; Christensen, J. B. Synth. Commun. 1998, $28,1223$.

10. El-Faham, A.; Abdul-Ghani, M. Org. Prep. Proced. Int. 2003, 35, 369.

11. Carpino, L. A.; Ionescu, D.; El-Faham, A.; Beyermann, M.; Henklein, P.; Hanay, C.; Wenschuh, H.; Bienert, M. Org. Lett. 2003, 5, 975.

12. (a) Thompson, R. Methods Enzymol. 1977, 46, 220. (b) Sharma, R. P.; Gore, M. G.; Akhtar, M. Chem. Commun. 1979, 875. (c) Bakker, A. V.; Jung, S.; Spencer, R. W.; Vinick, F.; Faraci, W. S. Biochem. J. 1990, 271, 559.

13. Pless, J.; Bauer, W.; Cardinaux, F.; Closse, A.; Hauser, D.; Huguenia, R.; Roemer, D.; Buescher, H. H.; Hill, R. C. Helv. Chim. Acta. 1979, 62, 398.

14. (a) Kokotos, G. Synthesis, 1990, 299. (b) Rodriguez, M.; Linares, M.; Doulut, S.; Heitz, A.; Martinez, J. Tetrahedron Lett. 1991, 32, 923.

15. Fehrentz, J. A.; Califano, J. C.; Amblard, M.; Loffet, A.; Martinez, J. Tetrahedron Lett. 1994, 35, 569.

16. Vogel's Textbook of Practical Organic Chemistry Longman: London $5^{\text {th }}$ Edn., 1989, $p$ 1222.

17. Giacomelli, G.; Porcheddu, A.; Salari, M. Org. Lett. 2003, 5, 2715. 